\title{
IgA antibody response to klebsiella in ankylosing spondylitis measured by immunoblotting
}

\author{
F Shodjai-Moradi, A Ebringer, I Abuljadayel
}

\begin{abstract}
IgA antibodies to Klebsiella pneumoniae var oxytoca and Proteus mirabilis were measured in 66 patients with ankylosing spondylitis (AS) and 31 with rheumatoid arthritis (RA) and in 51 healthy control subjects, using an immunoblotting technique. The number of antigenic bands to klebsiella on nitrocellulose membrane was higher in 28 patients with active AS than in 38 patients with inactive AS, 31 patients with $R A$, and 51 healthy control subjects; comparatively smaller increases were found against proteus. In two patients with AS the synovial fluid and the corresponding serum sample showed an identical antibody pattern. Increases in IgA antibodies to klebsiella in patients with AS confirm previous studies using other techniques.
\end{abstract}

Ankylosing spondylitis (AS) is a chronic systemic inflammatory disorder primarily affecting the axial skeleton, with lumbar spine and sacroiliac joint involvement being the hallmark of the disease. Patients often have marked fluctuations in symptoms and disease activity, which may resemble the response to an infection.

Demonstration of a high frequency of an HLA allele in AS has provided new approaches to the study of this disease. ${ }^{1}$ HLA-B27 is found in about $96 \%$ of patients with AS, attending the AS research clinic at the Middlesex Hospital in London, whereas it occurs in only $8 \%$ of the healthy white population. Microbiological studies show that klebsiella species are more commonly detected in the faeces of patients with active AS than in those of healthy controls. No such increased isolation is found for other Gram negative microorganisms, such as salmonella, shigella, or yersinia species, known to cause reactive arthritis, usually in subjects carrying the HLA-B27 antigen. ${ }^{2}$ In a survey of 39 different strains of klebsiella isolated from faecal samples obtained from patients with AS at the Middlesex Hospital, 14 were $K$ oxytoca (36\%), 24 were $K$ aerogenes $(62 \%)$, and one was $K$ pneumoniae (sensu strictu) $(3 \%) .^{3}$ All four species of the Gram negative microorganisms klebsiella, salmonella, shigella, and yersinia carry antigens cross reacting with HLA-B27, ${ }^{4-7}$ but only serological studies can distinguish which of these bacteria is associated with AS in HLA-B27 positive subjects. ${ }^{89}$ It has been suggested that after exposure to Gram negative bacteria AS is produced by antibodies to bacteria binding to cross reacting self antigens, such as HLA-B27, situated predominantly in the region of lymphatic drainage of the colon and rectum. ${ }^{10}$ To demonstrate the presence of such antibodies the following study was carried out with a western immunoblotting technique.

\section{Patients and methods}

PATIENTS AND CONTROLS

Serum samples were obtained from patients attending the AS research and rheumatoid arthritis (RA) gold clinics of the Middlesex Hospital. The diagnosis of AS was made by the New York criteria ${ }^{11}$ and that of RA according to the criteria of the American Rheumatism Association. ${ }^{12}$ The patients with AS were classified into those with active and inactive disease according to the erythrocyte sedimentation rate (ESR) and total serum IgA concentrations at the time of the study. Patients with active disease were defined as those with an ESR above 15 $\mathrm{mm} / \mathrm{h}$ and total serum IgA above $3 \mathrm{~g} / \mathrm{l}$, whereas patients with inactive AS had an ESR below 15 $\mathrm{mm} / \mathrm{h}$ and total serum IgA below $3 \mathrm{~g} / \mathrm{l}$. Patients with only one of these variables raised were deemed to be probably active and excluded from the study.

Serum samples obtained from 51 healthy subjects, aged between 20 and 56 years, who were either students or university staff, served as controls.

\section{ACUTE PHASE REACTANT AND SERUM IgA}

All serum samples were measured for $C$ reactive protein and total serum IgA using the single radial immunodiffusion technique of Mancini ${ }^{13}$ with commercially available reagents (Dako and Behringwerke). The ESR values of all patients were estimated by the Westergren method using the hospital service.

BACTERIAL STRAINS AND CULTURE CONDITIONS The Gram negative bacteria Klebsiella pneumoniae var oxytoca (MX 100) and Proteus mirabilis (B17) were maintained as bacterial cultures on nutrient agar slopes at room temperature. A starter culture comprising $24 \mathrm{ml}$ autoclaved $\left(121^{\circ} \mathrm{C}, 1.05 \mathrm{~kg} / \mathrm{cm}^{2}, 15\right.$ minutes) nutrient broth (Oxoid, $13 \mathrm{~g} / \mathrm{l}$ water) in a $250 \mathrm{ml}$ conical flask was inoculated from the agar slope, incubated at $37^{\circ} \mathrm{C}$ for six hours, and agitated at $250 \mathrm{rpm}$ on an orbital shaker. The shaker flask cultures were prepared by inoculating $200 \mathrm{ml}$ nutrient broth in a two litre conical flask with $10 \mathrm{ml}$ culture from the starter broth, incubated at $37^{\circ} \mathrm{C}$, and shaken for 16 hours at $250 \mathrm{rpm}$ on an orbital shaker. Overnight cultures were 
centrituged at $10000 \mathrm{rpm}$ for 20 minutes, washed three times in phosphate buffered saline (PBS) (pH 7.5), the pellet resuspended in $10 \mathrm{ml}$ PBS and ultrasonicated at an amplitude of 12 $\mu \mathrm{m}$ with 30 second bursts and 60 second rest periods (seven cycles).

\section{ANTIGEN PREPARATION FOR SODIUM DODECYL SULPHATE POLYACRYLAMIDE GEL \\ ELECTROPHORESIS (SDS-PAGE)}

The protein content of the sonicated sample of the microorganisms was measured by Bradford's protein assay. ${ }^{14}$ The sample was then diluted in sample buffer (final concentration: 0.05 $\mathrm{M}$ TRIS.HCl pH 6.8, 2 mM EDTA, 2\% SDS, 50 $\mathrm{mM}$ dithiothreitol, and $0.001 \%$ bromophenol blue) to a protein concentration of $1 \mathrm{mg} / \mathrm{ml}$ and allowed to dissociate for three hours at $37^{\circ} \mathrm{C}$. The samples were then subjected to SDSPAGE.

\section{SDS-PAGE}

Electrophoresis was performed in a discontinuous system, according to the method of Laemmli, ${ }^{15}$ with a $10 \%$ polyacrylamide resolving gel and a $3.5 \%$ stacking gel. A number of molecular weight markers (Sigma Chemical) were prepared at a concentration of $1 \mathrm{mg} / \mathrm{ml}$ in SDS sample buffer, and $100 \mu \mathrm{l}$ was applied to the gel. The polypeptide markers, in order of decreasing molecular weight, were phosphorylase B (94 000), bovine serum albumin (67 000), ovalbumin (43 000) carbonic anhydrase (30 000), soy bean trypsin inhibitor (20 100), and lactalbumin (14 400). The treated sample of the microorganism was also applied to the gel, after which electrophoresis was performed at a constant current of $50 \mathrm{~mA}$ until the bromophenol blue had travelled $10 \mathrm{~cm}$ in the resolving gel. The gels were either stained with Coomassie blue G-250 or immunoblotted, and molecular weights were estimated from a calibration curve obtained with standard proteins.

\section{IMMUNOBLOT ANALYSIS}

The separated components of the bacterium were transferred electrophoretically from the gel onto a sheet of nitrocellulose (Sartorius Membranes, pore size $0.45 \mu \mathrm{m}$ ), according to the method of Towbin. ${ }^{16}$

The transfer buffer was $25 \mathrm{mM}$ TRIS. $\mathrm{HCl}$, $192 \mathrm{mM}$ glycine (pH 8.3) containing 29\% $\mathrm{vol} / \mathrm{vol}$ methanol, and blotting was carried out

Table 1 General characteristics of the four study groups

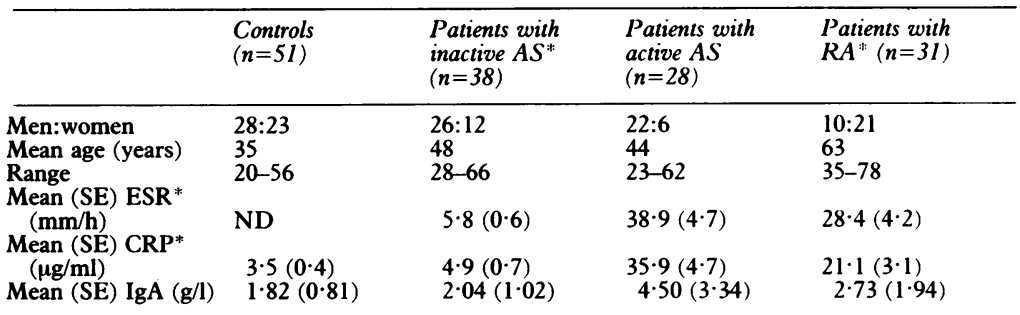

*AS=ankylosing spondylitis; $\mathrm{RA}=$ rheumatoid arthritis; $\mathrm{ESR}=$ erythrocyte sedimentation rate $\mathrm{CRP}=\mathrm{C}$ reactive protein. for one hour at $10 \mathrm{~V} / \mathrm{cm}$. After transfer the nitrocellulose sheet was cut into $3 \mathrm{~mm}$ strips, which were then shaken for two hours at room temperature in a blocking buffer $(5 \%$ casein, $7 \cdot 5 \%$ glycine, and $1 \%$ fraction $\mathrm{V}$ bovine serum albumin) to block the unoccupied protein binding sites. The strips were washed at room temperature by shaking with five changes (five minutes per wash) of $10 \%$ PBS containing $0 \cdot 1 \%$ Tween and $1 \%$ casein. Each strip was then incubated with a different patient serum overnight at $4^{\circ} \mathrm{C}$. The serum samples were diluted $1: 50$ in saline ( $20 \mathrm{mM}$ TRIS, $500 \mathrm{mM} \mathrm{NaCl}$, pH $7 \cdot 5$ ) containing $3 \%$ casein. The strips were then washed in PBS containing casein and Tween 20 , as described above, and then shaken for two hours at room temperature with horseradish peroxidase conjugated rabbit antihuman IgA (Dako, specific for $\alpha$ chains) (dilution 1:750). After a washing step the antigen-antibody complexes were visualised by addition of the substrate solution $(0.02 \%$ 4-chloro-l-naphthol and $0.005 \%$ hydrogen peroxide in $0.075 \% \mathrm{M}$ TRIS.HCl buffer, $\mathrm{pH} 7 \cdot 4$ ). The reaction was stopped after 20 minutes by washing the strips in distilled water. The number of bands developed were counted while the strips were wet. All immunoblotting studies were carried out under code. No lines were found to be present when the nitrocellulose strips were treated only with second antibody-namely, peroxidase conjugated rabbit antihuman $\operatorname{IgA}$.

\section{Results}

GENERAL CHARACTERISTICS OF THE FOUR STUDY GROUPS

Table 1 summarises the characteristics of the four groups: controls, patients with inactive and active AS, and patients with RA. The number of men and women in the control group was almost equal whereas the ratio of men to women in the group with active AS was $4: 1$, in the group with inactive AS 2:1, and in the rheumatoid group 1:2. The mean age of both groups with AS was in the forties, that of the control group was in the thirties, and that of the group with RA was in the early sixties.

The mean ESR in the group with active AS was significantly higher than that found in the group with inactive disease $(t=7 \cdot 84, p<0.001)$ but not significantly different when compared with the group with RA. The mean ESR in the group with RA was significantly raised in comparison with the group with inactive AS $(t=6.07, p<0.001)$. The ESR values of the controls were not measured.

The mean $C$ reactive protein in the group with active AS was significantly higher than that in groups with $R A(t=2.69, p<0.01)$ and inactive AS $(t=7.58, p<0.001)$ and in the controls $(t=9 \cdot 27, p<0 \cdot 001)$.

The mean serum IgA concentration in the group with active AS was significantly raised compared with that in the groups with $\mathrm{RA}$ $(t=4.69, p<0.001)$ and inactive AS $(t=7.93$, $p<0.001)$ and in the controls $(t=10.87$, $\mathrm{p}<0.001)$. The mean serum IgA of the group with RA was significantly higher than that of the group with inactive AS $(t=3.29, p<0.005)$ 


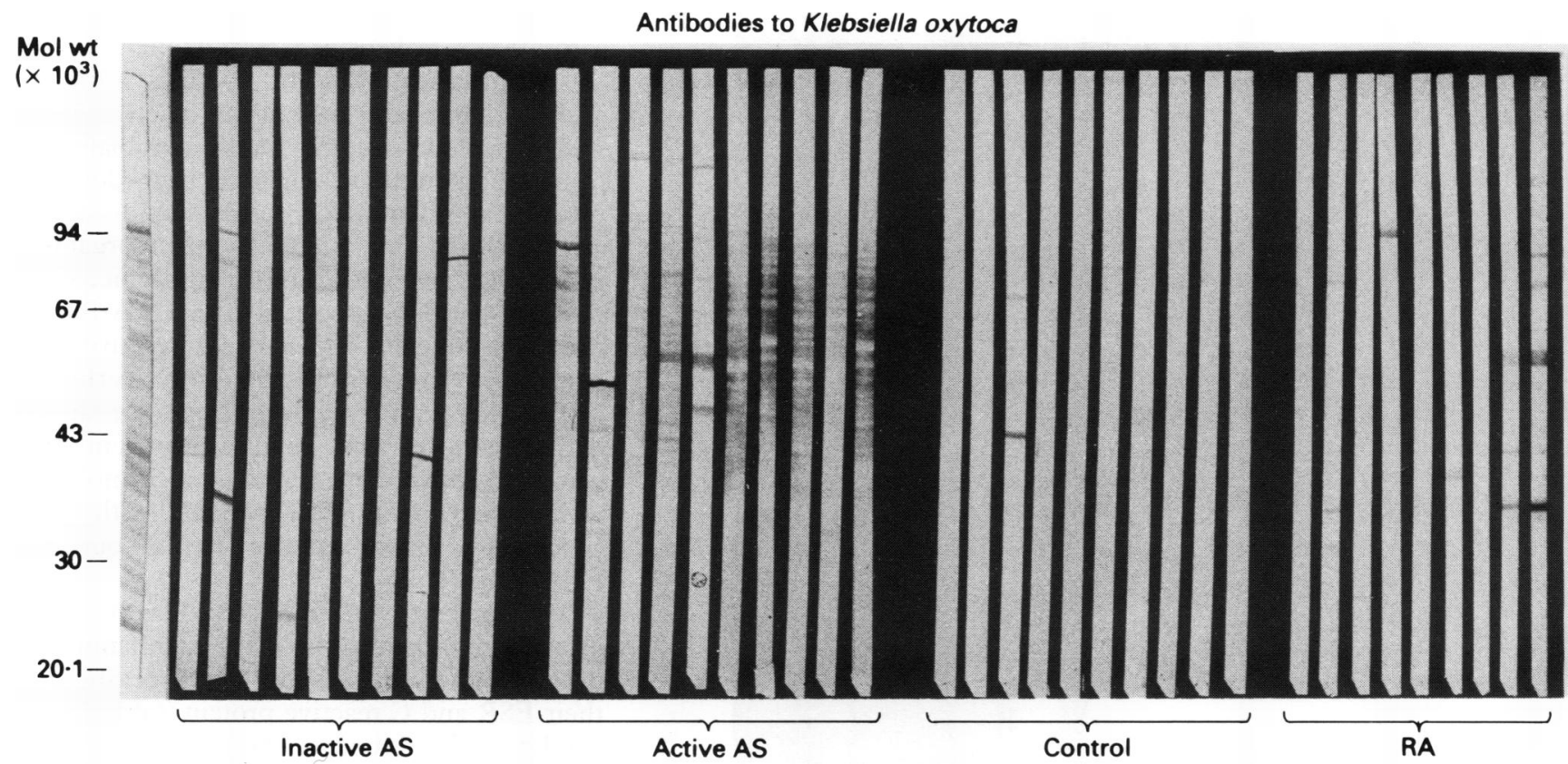

Figure I Immunoblotting antigenic bands developed with serum samples from patients with inactive and active AS, from controls, and from patients with $R A$ against sonicated Klebsiella oxytoca. Molecular weight markers $\left(\times 10^{3}\right)$ are also indicated.

and the control group $(t=6.02, p<0.001)$. The mean serum IgA concentration of the group with inactive AS was not significantly different from that found in the control group.

\section{ANALYSIS OF THE RESULTS FROM THE IMMUNOBLOTTING ASSAY \\ Klebsiella study}

Figure 1 shows a typical immunoblot of serum samples obtained in this study. The first strip on the left shows the protein profile of Klebsiella oxytoca after being separated by SDS-PAGE, transferred onto nitrocellulose paper and stained with amido black. Molecular weight markers are also indicated.

The antigenic bands on each strip were counted, the origin of the serum samples decoded, and the mean calculated. Table 2 shows the results obtained. The mean number of bands in the group with active AS was significantly higher than that in the groups with inactive $A S(t=8.65, p<0.001)$ and $R A(t=11.46$, $\mathrm{p}<0.001)$ and in controls $(\mathrm{t}=15 \cdot 10, \mathrm{p}<0.001)$.

The mean number of bands in the group with inactive AS was also significantly higher than that in the control group $(t=2 \cdot 76, p<0 \cdot 01)$, but not than that in the group with RA. There was no significant difference in the mean number of bands between the group with RA and the control group.

Table 2 Number of antigenic bands measured by immunoblotting against both klebsiella and proteus microorganisms in the four study groups. Results are given as mean (SE)

\begin{tabular}{|c|c|c|c|c|}
\hline & $\begin{array}{l}\text { Controls } \\
(n=51)\end{array}$ & $\begin{array}{l}\text { Inactive } A S^{*} \\
(n=38)\end{array}$ & $\begin{array}{l}\text { Active AS } \\
(n=28)\end{array}$ & $\begin{array}{l}R A^{*} \\
(n=31)\end{array}$ \\
\hline $\begin{array}{l}\text { Number of } \\
\text { antigenic bands } \\
\text { against klebsiella }\end{array}$ & & $3.7(0.7)$ & $13.0(0.9)$ & $2 \cdot 2(0 \cdot 4)$ \\
\hline $\begin{array}{l}\text { Number of } \\
\text { antigenic bands } \\
\text { against proteus }\end{array}$ & $0.7(0.1)$ & $1 \cdot 3(0 \cdot 2)$ & $3.0(0.5)$ & $1.4(0.3)$ \\
\hline
\end{tabular}

${ }^{*} \mathrm{AS}=$ ankylosing spondylitis; $\mathrm{RA}=$ rheumatoid arthritis .
The means between the groups were compared by Student's $t$ test.

The $95 \%$ confidence limit for the control group was $4 \cdot 0$ lines (mean $+1 \cdot 6 \mathrm{SD}$ ).

Most serum samples from the group with active AS produced more than four lines per nitrocellulose strip.

As we were not trying to identify those AS serum samples which were positive compared with control samples-that is, those exceeding the $95 \%$ confidence limits, but were comparing only means between the groups, the analysis was carried out with Student's $t$ test.

\section{Proteus study}

As for the klebsiella study, IgA antibodies were measured by counting the number of antigenic bands visualised on the nitrocellulose membrane and the mean was calculated. Table 2 shows the results obtained.

The mean number of bands in the group with active AS was significantly higher than that in the groups with inactive AS $(t=3.51, p<0.001)$ and RA $(t=2.96, p<0.005)$ and in the control group $(t=5.04, p<0.001)$.

\section{COMPARISON OF SERUM AND SYNOVIAL FLUIDS}

Paired samples of serum and synovial fluid from two patients with AS with knee effusions, one with active and the other with inactive disease, were tested against a sonicated preparation of klebsiella using a horseradish peroxidase conjugated antihuman $\operatorname{IgA}$, as previously described. Each patient's synovial fluid and the corresponding serum sample showed exactly the same pattern of bands on the immunoblot (fig 2). The number and intensity of bands in the serum and synovial fluid obtained from the patient with inactive AS (A) was less than that of the bands in the fluids from the patient with active disease (B) (fig 2). 


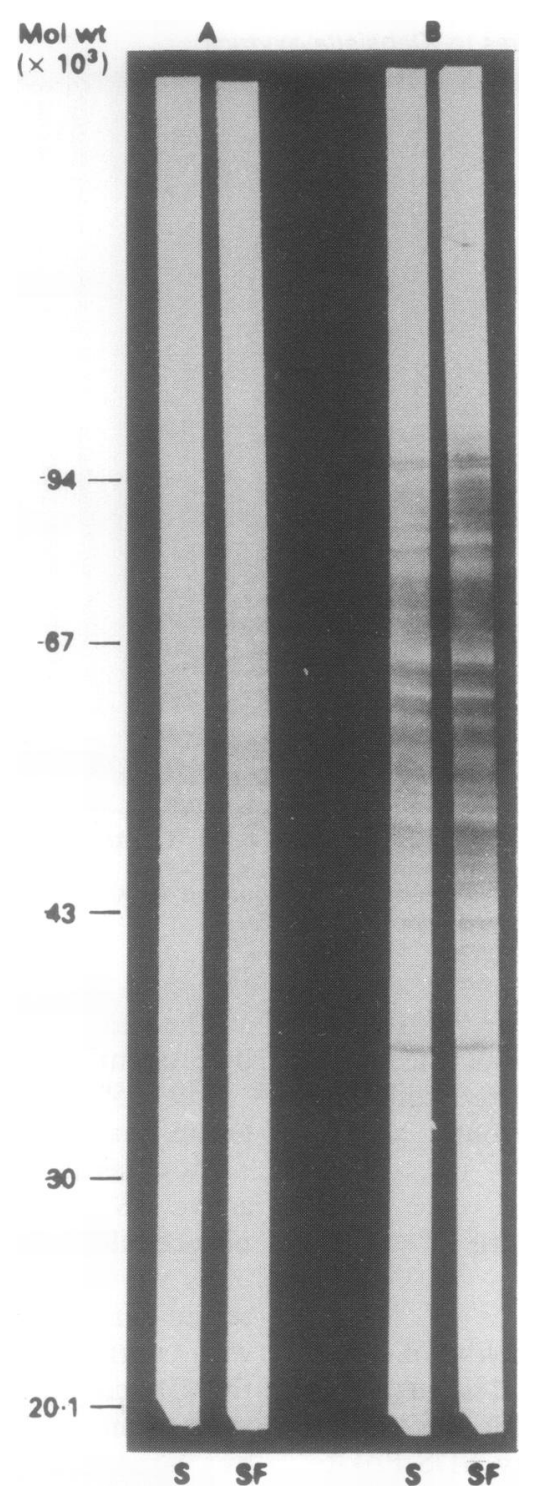

Figure 2 IgA antibodies to klebsiella in serum $(S)$ and synovial fluid $(S F)$ in two patients with ankylosing spondylitis, one with inactive $(A)$ and the other with active $(B)$ disease, detected by immunoblotting.

\section{Discussion}

Immunoblotting showed that patients with active AS have an increased number of $\operatorname{IgA}$ antibodies to different Gram negative bacterial components of klebsiella and, to a lesser extent, to proteus microorganisms. This is in agreement with earlier reports of raised antibodies to klebsiella in patients with active AS measured by enzyme linked immunosorbent assay (ELISA), ${ }^{8}{ }^{9}$ bacterial absorption, ${ }^{17}$ and indirect Coombs' bacterial agglutination. ${ }^{18}$ The increased levels of IgA antibodies might indicate enterobacterial antigenic stimulation via the gastrointestinal tract during active phases of the disease. Isolation of klebsiella from faecal samples obtained from patients with active AS was reported some years $\mathrm{ago}^{2}$ and subsequently confirmed by two other independent groups. ${ }^{19} 20$ Biochemical studies confirmed that phases of increased disease activity were associated not only with a raised $C$ reactive protein concentration and $\mathrm{ESR}^{21}$ but also with an increase in total serum $\operatorname{IgA}$, thereby suggesting that a bacterial antigenic trigger might be acting across a mucosal surface, such as the gut. ${ }^{22}$

This demonstration of specific antibodies against klebsiella in patients with active AS, as well as isolation of the same microbial agent from stool cultures, suggests, but does not prove, that inflammatory relapses in this disease are triggered by klebsiella microorganisms rather than by other, more pathogenic, Gram negative bacteria associated with HLA-B27, as occurs in shigella and yersinia reactive arthritis. ${ }^{23}$ An immunoblotting assay performed under code with Yersinia enterocolitica showed antibodies to yersinia in Finnish patients with yersinia reactive arthritis, but no such antibodies were found in English patients with $\mathrm{AS},{ }^{24}$ confirming similar studies carried out with ELISA. ${ }^{9}$

The patients with RA served as a control group with inflammatory disease. Inflammatory disease activity in this group, as measured by their ESR and C reactive protein (table 1), was similar to that found in the group with active AS, but the rheumatoid patients did not show any significant increase of IgA antibodies to either klebsiella or proteus. Another immunoblotting study, however, found that patients with active RA had an increased number of IgG antibodies when tested against Proteus mirabilis. ${ }^{25}$ Gram negative bacteria share common antigens, and thus it is not surprising that serum samples from patients with active AS detected between three and four proteus antigenic bands, though the number detected against klebsiella was clearly much higher. In some patients with AS up to 25 klebsiella bands were detected.

Careful examination of the blots showed that the patients with active AS had antibodies to a number of klebsiella bacterial components with molecular weights ranging from 43000 to 94000 . The common bands among the patients with active AS were to proteins with molecular weights 102000 (22\%), 90000 (30\%), 65000 $(37 \%)$, and $48000(19 \%)$. None of the control serum samples had antibodies against the 65000 and 48000 proteins. Whether or not these proteins are involved in the pathogenesis of the disease deserves more attention and further study. In a recent report Van Bohemen and coworkers suggested that patients with AS had antibodies to a common outer membrane protein (approximate molecular weight 35000 ) found in Klebsiella pneumoniae (K43), Shigella flexneri (2a), and Yersinia enterocolitica (9). ${ }^{26}$

An independent study was also carried out on two paired samples of serum and synovial fluid obtained from patients with AS, which showed a similar IgA antibody pattern in the serum and synovial fluid against a sonicated preparation of klebsiella. Although this may suggest that antibodies to klebsiella found in synovial fluid might have been derived from circulating immunoglobulins, clearly more such paired studies are required to determine the consistency of this observation.

Although the presence of specific antibodies to klebsiella ${ }^{27}$ confirms indirectly the bacteriological studies of increased klebsiella isolation in patients with active AS, the mechanism by 
which the bacteria, or the antibodies evoked against them, produce the lesions of the disease remains a subject of speculation and further study.

Other workers have also carried out antibody investigations in AS and found raised titres against klebsiella microorganisms.

A group from Glasgow investigated 64 patients with AS, 25 with RA, 30 with Crohn's disease, 20 with ulcerative colitis, and 35 controls using an ELISA on $K$ pneumoniae (K43) as target antigen. The results of their studies showed that antibodies to klebsiella were raised not only in AS, but also in ulcerative colitis, Crohn's disease, and RA when compared with controls. ${ }^{28}$

Their conclusions differ from ours as they suggest that patients with AS have a 'leaky' gut mucosa because of bowel inflammation, which allows all gut bacteria to penetrate across the bowel.

Clearly, further comparative studies are required to resolve these differences, but there seems to be agreement that bacterial antigens evoke an immune response in patients with AS which explains the increase in total serum IgA.

At this stage it is not clear whether this antigenic factor has a specific pathological role or only represents a non-specific, immunological marker of a compromised bowel mucosa.

We thank the trustees of the Middlesex Hospital for their support.

1 Ebringer A. The link between genes and disease. New Scientist 1978; 79: 865-7.

2 Ebringer R W, Cooke D, Cawdell D R, Cowling P, Ebringer A. Ankylosing spondylitis, klebsiella and HLA-B27. Rheumatol Rehabil 1977; 16: 190-6.

3 Pease P E, Tyler R A, England J R, Colthorpe D, Ebringer A. An investigation into the properties of klebsiella strains isolated from ankylosing spondylitis patients. $\mathfrak{F}$ Hyg (Lond) 1982; 89: 119-23.

4 Ebringer A, Cowling P, Ngwa-Suh N, James D C O, Ebringer $R$ W. Cross-reactivity between klebsiella aeroEbringer $R$. Cross-reactivity between klebsiella aerogenes species and B27 lymphocyte antigens as an aetiological factor in ankylosing spondylitis. In: Dausset J, Svejgaard
$\mathrm{A}$, eds. HLA and disease. Vol 58. Paris: INSERM, 1976: A,

5 Avakian H, Welsh J, Ebringer A, Entwistle C C. Ankylosing spondylitis, HLA-B27 and klebsiella. II. Cross-reactivity studies with human tissue typing sera. Br $\mathcal{F}$ Exp Pathol 1980; 61: 92-6.

6 Van Bohemen Ch G, Grumet F C, Zanen H C. Identification of HLA-B27 M1 and $M 2$ cross-reactive antigens in klebsiella, shigella and yersinia. Immunology 1984; 52: 607-9.

7 Kono D H, Ogasawara M, Effros R B, Park M S, Waldord
R L, Yu D T Y. Ye-1, a monoclonal antibody that crossreacts with HLA-B27 lymphoblastoid cell lines and an arthritis causing bacteria. Clin Exp Immunol 1985; 61: arthritis

8 Trull A, Ebringer R, Panayi G S, Colthorpe D, James D C O, Ebringer A. IgA antibodies to klebsiella pneumoniae in ankylosing spondylitis. Scand $\mathcal{f}$ Rheumatol 1983; 12: 249-53.

9 Trull A, Ebringer A, Panayi G S, Ebringer R, James D C O. HLA-B27 and the immune response to enterobacterial antigens in ankylosing spondylitis. Clin Exp Immunol 1984; 55: 74-80.

10 Ebringer A. The cross-tolerance hypothesis, HLA-B27 and ankylosing spondylitis. $B r \mathcal{F}$ Rheumatol 1983; 22 (suppl 2): 53-66.

11 Bennet P H, Wood P H N. Population studies of the rheumatic diseases. Amsterdam: Excerpta Medica, 1968: 456.

12 Ropes M W, Bennett G A, Cobb S, Jacox R, Jessar R A. revision of diagnostic criteria for rheumatoid arthritis. Bull revision of diagnostic crite

13 Mancini G, Carbonara H O, Heremans J F. Immunological quantification of antigens by single radial immunodiffusion.

14 Bradford $M$. A rapid and sensitive method for the quantitation of microgram quantities of protein utilising the principle of protein dye binding. Anal Biochem 1976; 72: 248-54.

15 Laemmli U K. Cleavage of structural proteins during the assembly of the head of bacteriophage T4. Nature 1970; 227: $680-5$.

16 Towbin H, Stachelin T, Gordon J. Electrophoresis transfer of proteins from polyacrylamide gels to nitrocellulose sheets: procedure and some applications. Proc Natl Acad Sci USA 1979; 76: 4350-7.

17 Ebringer A, Baines $\mathbf{M}$, Childerstone $\mathbf{M}$, Ghuloom $\mathbf{M}$, Ptaszynska T. Etiopathogenesis of ankylosing spondylitis and the cross-tolerance hypothesis. In: Ziff $\mathbf{M}$, Cohen S B, and the cross-tolerance hypothesis. In: Ziff $M$, Cohen $S \mathrm{~B}$, eds. Advances in inflammation research: the spondyloarthro
pathies. Vol 9. New York: Raven Press, 1985: 101-28.

18 Ebringer A, Ptaszynska T, Corbett M, et al. Antibodies to proteus in rheumatoid arthritis. Lancet 1985; ii: 305-7.

19 Hunter H, Harding G K M, Kaprove R E, Schroeder M L. Fecal carriage of various klebsiella and enterobacter species in patients with active ankylosing spondylitis. Arthritis Rheum 1981; 24: 106-8.

20 Kuberski T T, Morse H G, Rate R G, Bonnell M D. Increased recovery of klebsiella from the gastrointestinal tract of Reiter's syndrome and ankylosing spondylitis patients. Br f Rheumatol 1983; 22 (suppl 2): 85-90.

21 Cowling P, Ebringer R, Cawdell D, Ishii M, Ebringer A. C-reactive protein, ESR and klebsiella in AS. Ann Rheum Dis 1980; 39: 45-9.

22 Cowling P, Ebringer R, Ebringer A. Association of inflammation with raised serum IgA in ankylosing spondylitis. mation with raised serum IgA

23 Aho K. Yersinia reactive arthritis. Br f Rheumatol 1983; 22 (suppl 2): 41-5.

24 Toivanen A, Stahlberg T H, Granfors K, Ebringer A. Absence of antibodies in Yersinia enterocolitica in patients with ankylosing spondylitis in London. Lancet 1986; ii: 1400 .

25 Ebringer A, $\operatorname{Cox} \mathrm{N}$ L, Abuljadayel I, et al. Klebsiella antibodies in ankylosing spondylitis and proteus antibodies in rheumatoid arthritis. $\mathrm{Br} 7$ Rheumatol 1988; 27 (suppl 2): $72-85$.

26 Van Bohemen Ch G, Weterings E, Coei H S, Grumet F'C Zanen HC. Enterobacterial involvement in the pathogenesis Zanen HC. Enterobacterial involvement in the pathogenesis 27 (suppl 2): 61-7.

27 Ebringer A. The relationship between klebsiella infection and ankylosing spondylitis. Balliéres Clin Rheumatol 1989; 2 ankylosing

28 Cooper R, Fraser S M, Sturrock R D, Gemmel C G. Raised titres of anti-klebsiella IgA in ankylosing spondylitis, rheumatoid arthritis and inflammatory bowel disease. $B M \mathcal{Y}$ 1988; 296: 1432-4. 